\title{
Rancang Bangun Fitur Pengelolaan Penyaringan Produk Pada Situs Penjualan Produk Perangkat Lunak untuk Mempermudah Pencarian
}

\author{
Umar Al Aqsho, Rully Agus Hendrawan, dan Andre Parvian Aristio \\ Departemen Sistem Informasi, Fakultas Teknologi dan Informasi, Institut Teknologi Sepuluh \\ Nopember (ITS) \\ e-mail : eraha[at]is.its.ac.id
}

\begin{abstract}
Abstrak-Produk merupakan informasi yang dicari oleh pengguna, pengguna dapat berbagi, berkomentar, berlangganan, menyumbangkan, mengikuti atau membeli dari produk yang tersebar secara online. Saat ini, pengguna perlu memikirkan atau melakukan brainstorm keyword jika ingin mencari produk yang dibutuhkan. Namun, sering kali keyword untuk mencari produk yang dibutuhkan tersebut tidak terpikirkan dan keyword harus terus menerus dipertajam. Sehingga pengguna butuh usaha lebih untuk memahami kebutuhan dirinya sendiri. Pengguna juga tidak dapat menemukan produk yang mereka butuhkan dikarenakan salah memasukan keyword pencarian, meskipun sebenarnya produk/solusi tersedia. Filter search mengacu kepada: teknik untuk mengakses informasi yang telah ditata berdasarkan klasifikasi, yang memungkinkan pengguna untuk menjelajahi kumpulan informasi dengan menerapkan beberapa nilai terhadap pencariannya. Pembangunan prototipe dengan tujuan mendapatkan upan balik sehingga dapat menciptakan hasil akhir yang baik serta dapat dilakukan pengujian kepada pengguna secara langsung mengenai pencarian dan penyaringan produk, dengan pengujian dapat diketahui bahwa produk yang pengguna cari dan pilih sesuai dengan yang dibutuhkan oleh mereka Dihasilkan penyimpanan pencarian dan penyaringan yang telah dilakukan oleh pengguna menjadi sebuah template pencarian. Dengan diciptakannya prototipe aplikasi ini didapatkan 71,25 kemudahan penggunaan yang menunjukan prototipe dapat digunakan untuk memudahkan pengguna dalam mencari produk aplikasi yang dibutuhkan.
\end{abstract}

Kata Kunci_Produk, Pengelolaan Penyaringan, Filter Search, Prototipe, Penyaringan.

\section{PENDAHULUAN}

$\mathrm{K}$ ONTEN adalah mata uang dari web sosial. Konten merupakan informasi yang dicari oleh pengguna, konten adalah hal yang membuat penguna melakukan klik, berbagi, komentar, berlangganan, menyumbangkan, mengikuti atau membeli dari Anda [1]

Namun, saat mencari konten/produk pengguna dihadapi masalah dengan hasil pencarian mana yang paling cocok dengan kebutuhan penguna/pemilik mobile device. Hasil pencarian yang ada saat ini biasanya didapatkan berdasarkan kesamaan/kemiripan teks atau kata kunci, bukan berdasarkan kebutuhan yang pengguna inginkan. Maka dibutuhkan pencarian dan penyaringan yang sesuai dengan kebutuhan untuk membantu pengguna mendapatkan produk yang tepat bagi mereka.
Faceted search mengacu kepada: teknik untuk mengakses informasi yang telah ditata berdasarkan klasifikasi, yang memungkinkan pengguna untuk menjelajahi kumpulan informasi dengan menerapkan beberapa filter terhadap pencariannya [2]. Faceted search ini dapat digunakan untuk membuat manajemen konteks, manajemen konteks adalah pendekatan baru untuk perancangan sistem yang sadar terhadap konteks yang dapat menginstegrasikan personalisasi dari pengguna dengan pemodelan konteks sehingga sistem bisa mendapatkan keuntungan dari personalisasi pengguna maupun model konteks dan menciptakan model yang lebih valid untuk personalisasi serta konteks informasi yang didapat [3].

Dengan menerapkan faceted search pengguna bisa mendapatkan pilihan kondisi yang terkait dengan pencariannya sehingga pengguna dapat menemukan produk yang sesuai. Dengan faceted search pengguna juga tidak perlu kebingungan terhadap keyword/kata kunci untuk mencari produk karena pengguna diberikan pilihan penyaringan sesuai dengan konteks kebutuhan yang pengguna inginkan [4].

Pembangunan prototipe dengan tujuan mendapatkan upan balik sehingga dapat menciptakan hasil akhir yang baik serta dapat dilakukan pengujian kepada pengguna secara langsung mengenai pencarian dan penyaringan produk, dengan pengujia dapat diketahui bahwa konten/produk yang pengguna cari dan pilih sesuai dengan yang dibutuhkan oleh mereka [5].

Pada era perdagangan yang semakin berkembang ini, para penjual ingin memiliki katalog produk yang besar dan terlengkap sehinggan koten yang dimiliki oleh penjual menjadi semakin ramai. Namun, pengguna saat ini lebih memilih untuk mencari dan membeli produk yang mereka butuhkan, tetapi banyak yang merasakan kebingungan dengan banyaknya pilihan yang ditawarkan, sehingga pengguna ditantang untuk menyaring dan mencari konten yang berkualitas [6]. Ketika hasil tidak ditemukan pengguna perlu terus menerus mempertajam kata kunci pencarian untuk menemukan produk yang dibutuhkan.

Hasil dari penelitian ini adalah sebuah aplikasi web berbasis PHP/HTML yang dapat membantu pencarian dan penyaringan konteks, dengan adanya aplikasi ini diharapkan dapat digunakan untuk meningkatkan paparan produk kepada konsumen sehingga dapat membantu peningkatan penjualan serta mempercepat untuk menemukan produk yang sesuai 
dengan kebutuhan diri pengguna.

\section{DASAR TEORI}

\section{A. Google Play API}

Google Play adalah layanan distribusi digital, yang juga merupakan toko media digital, Google Play (yang pada awalnya bernama Android Market), dikelola dan dikembangkan oleh Google. Google Play berfungsi sebagai toko aplikasi resmi khusus untuk sistem operasi mobile android, yang memungkinkan pengguna untuk mencari dan mengunduh aplikasi yang dikembangkan dengan Android SDK dan dipublikasikan melalui Google. Google Play juga berfungsi sebagai toko media digital yang menawarkan musik, majalah, buku, film, dan program televisi [7]. Google Play API adalah Application Programming Interface yang disediakan untuk memudahkan pembangunan perangkat lunak yang berhubungan dengan data Google Play. Google Play API menyediakan motode untuk melakukan pengambilan data langsung dari Google Play yang akan digunakan dalam penelitian ini.

\section{B. Search in Relational Database}

Pencarian dalam basis data relasional menerapkan teknik pencarian kata kunci dalam bentuk basis data teks/information retrieval (IR) ke basis data relasional (DB). Teknik ini merupakan tugas yang menantang karena terdapat dua jenis basis data yang berbeda. Pertama, yaitu dalam basis data teks, unit informasi yang dicari oleh pengguna adalah dokumen. Untuk permintaan kata kunci tertentu, sistem IR akan menghitung skor numerik untuk setiap dokumen dan menentukan peringkat dokumen dengan skor ini. Dengan menerapkan pencarian dalam basis data relasional, pengguna tidak perlu tahu skema basis data atau menggunakan bahasa query yang terstruktur untuk melakukan pencarian. Sebaliknya, pengguna hanya perlu menyerahkan daftar kata kunci dengan menggunakan antarmuka yang sangat sederhana, dan mesin pencari menampilkan hasil dokumen yang di-ranking berdasarkan relevansi dengan permintaan dari teks basis datanya. Dengan demikian pencarian data/dokumen yang tersimpan dalam basis data akan menjadi lebih mudah [8]. Search in Relational Database merupakan dokumentasi untuk mempelajari dan mengembangkan pencarian dan penyaringan aplikasi yang dibangun pada penelitian ini terutama pada bagian SQL untuk query select dan where.

\section{Prototyping \& Usability Testing}

Prototyping merupakan strategi yang sangat baik untuk melakukan desain yang efektif dengan menciptakan desain produk. Prototipe bukan sebuah produk yang sudah jadi secara utuh, melainkan produk yang dapat digunakan fungsifungsinya sebagai uji coba agar memudahkan pendesain dalam mendapatkan feedback. Harus diperhatikan dengan baik bahwa tujuan terpenting dari prototipe adalah mendapatkan feedback. Dengan melakukan prototipe, pendesain dapat terus menyempurnakan produk akhir yang ingin dihasilkan berdasarkan feedback yang diterima dari partisipan [5]. Setelah prototipe dihasilkan dilakukan pengujian usabilitas. Dengan pengujian usabilitas, produk yang telah dihasilkan dapat dievaluasi. Proses pengujian usabilitas ini dilakukan oleh partisipan, dengan cara partisipan mencoba menyelesaikan beberapa task sambil diawasi oleh pengamat. Tujuannya adalah menemukan masalah usabilitas dari produk yang dihasilkan dan mengumpulkan data kuantitatif serta kualitatif yang ditentukan dari kepuasan/harapan partisipan terhadap produk yang diujikan [9].

\section{METODOLOGI}

\section{A. Studi Literatur}

Pada tahap studi literatur, penulis mengumpulkan informasi yang nantinya digunakan untuk mengusulkan solusi terkait dengan permasalahan pencarian dan penyaringan kebutuhan pengguna. Pengumpulan data dan informasi sendiri dilakukan dengan cara membaca referensi dari buku dan penelitian-penelitian yang telah dilakukan sebelumnya. Tujuan dari tahap ini agar penulis dapat memahami dasar teori yang berhubungan dengan permasalahan dan dapat mempermudah dalam menemukan solusi yang tepat.

\section{B. Studi Literatur}

Tahap studi literatur merupakan tahap kedua dari pengerjaan studi. Pada tahapan ini dilakukan pengkajian terhadap permasalahan yang akan diangkat, rumusan masalah, tujuan dan manfaat dari penelitian yang dilakukan. Selain itu, pada tahapan ini dilakukan berbagai kajian pustaka mengenai konsep optimasi serta metode yang akan digunakan dalam menyelesaikan permasalahan pada studi. Studi literatur tersebut kemudian digunakan sebagai landasan teori atau acuan dalam pengerjaan studi mengenai konsep optimasi, Integer Linear Programming, dan Sistem Informasi Geografis.

\section{Pencarian Kebutuhan}

Tahapan ini dilakukan untuk mengetahui kebutuhan dari pengguna dalam menemukan produk yang sesuai dengan kebutuhan dirinya. Setelah mendapatkan data kebutuhan pengguna dan mempelajari kajian mengenai teknik pembangunan pencarian dan penyaringan produk maka diperlukan ekstraksi data kategori, app permission, similar app, serta sugessted pada Google Play.

\section{Perancangan Prototipe}

Setelah mendapatkan data ekstraksi produk dari Google Play, maka langkah selanjutnya adalah membuat perancangan prototipe dan merancang prototipe sesuai dengan kebutuhan pengguna mengenai pencarian dan penyaringan produk. Tujuan utama dari Studi ini adalah pembuatan aplikasi web berbasis PHP/HTML yang dapat membatu pencarian dan penyaringan konteks. Luaran dari tahapan perancangan prototipe adalah web aplikasi berbasis PHP/HTML yang mampu menampilkan pencarian dan penyaringan produk serta tagging kategori yang sesuai dengan hasil pencarian produk.

\section{E. Pengujian Aplikasi}

Selanjutnya aplikasi akan diuji usabilitasnya. Apabila hasil uji usabilitas lebih rendah dari yang diharapkan maka desain akan diubah sesuai dengan harapan pengguna. Namun, dalam konteks studi ini, hasil pengujian usabilitas akan digunakan sebagai bahan evaluasi perbaikan sistem di masa yang akan datang. 


\section{PERANCANGAN}

\section{A. Proses Pembuatan Model Optimasi}

Metode Integer Linear Programming akan digunakan untuk membuat model yang sesuai dengan tujuan dari penelitian. Pada tahapan ini terdapat tiga langkah, yaitu:

\section{Wawancara Kebutuhan}

Wawancara digunakan untuk mencari kebutuhan pengguna perangkat serta ekspetasi pengguna terhadap aplikasi yang akan dibangun. Dari wawancara kebutuhan dilakukan analisis terhadap kebutuhan pengguna dari aplikasi yang akan dikembangkan. Wawancara dilakukan pada tanggal 21 Maret 2017 kepada.

Tabel 1.

Kebutuhan pengguna

\begin{tabular}{ll}
\hline \hline $\begin{array}{l}\text { ID user needs } \\
\text { Tujuan: Membuat aplikasi yang dapat menyaring pencarian kata kunci. }\end{array}$ \\
\hline UN001 & $\begin{array}{l}\text { Pengguna aplikasi dapat mencari produk aplikasi } \\
\text { dengan kata kunci. }\end{array}$ \\
UN002 & $\begin{array}{l}\text { Pengguna aplikasi dapat menambahkan } \\
\text { penyaringan dari kata kunci pencarian. }\end{array}$ \\
UN003 & $\begin{array}{l}\text { Pengguna aplikasi dapat dengan mudah } \\
\text { menemukan produk yang sesuai dengan } \\
\text { kebutuhannya }\end{array}$ \\
Tujuan: Menyediakan sistem yang dapat memepermudah dan \\
mempercepat pencarian
\end{tabular}

\section{Perancangan Pengambilan Data}

Pengambilan data dilakukan untuk mendapatkan produk aplikasi yang akan digunakan dalam pencarian dan penyaringan. Untuk melakukan proses pengambilan data, dapat digunakan API yang diciptakan sesuai dengan stuktur situs Google Play sehingga data dapat dengan mudah diambil. API yang digunakan berasal dari gooplayapi.herokuapp.com yang diciptakan oleh Natanael Yabes W [10]. Data yang diambil adalah seluruh struktur data setiap produk aplikasi yang ada pada Google Play. Alur pengambilan data yang dilakukan pada Google Play API dapat dilihat pada Gambar 1:

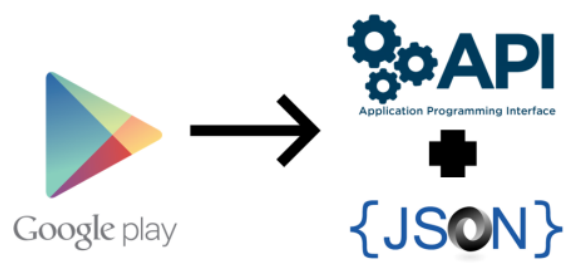

Gambar 1. Alur pengambilan data sebelum dimodifikasi dari google play

Data yang dimasukkan ke basis data ini bersifat umum dan spesifik. Data umum ini adalah data semua produk aplikasi pada Google Play yang hanya menampilkan data secara umum mengenai aplikasi tersebut. Data spesifik adalah data yang berisikan satu aplikasi namun menampilkan data secara detail. Data umum dan spesifik kemudia dijadikan 1 tabel, yaitu tabel applications pada basis data. Proses pengambilan data dari API + JSON memiliki alur yang dapat dilihat pada Gambar 2:

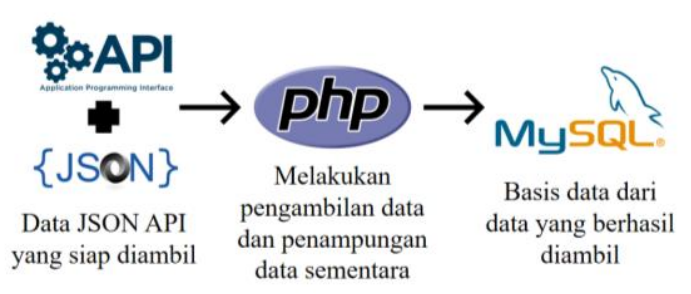

Gambar 2. Alur pengambilan data dari api + json

\section{Rancang Bangun Prototipe}

Berikut ini merupakan desain antar muka pengguna aplikasi. Antar muka yang dibuat terdir dari dua antar muka; halaman pencarian dan halaman hasil pencarian. Untuk setiap antar muka pengguna yang dibuat, akan dijadikan acuan dalam pengembangan use case.

Google Play searcher

Sistem pencarian aplikasi pada Google Play yang sesuai dengan kebutuhan pengguna.

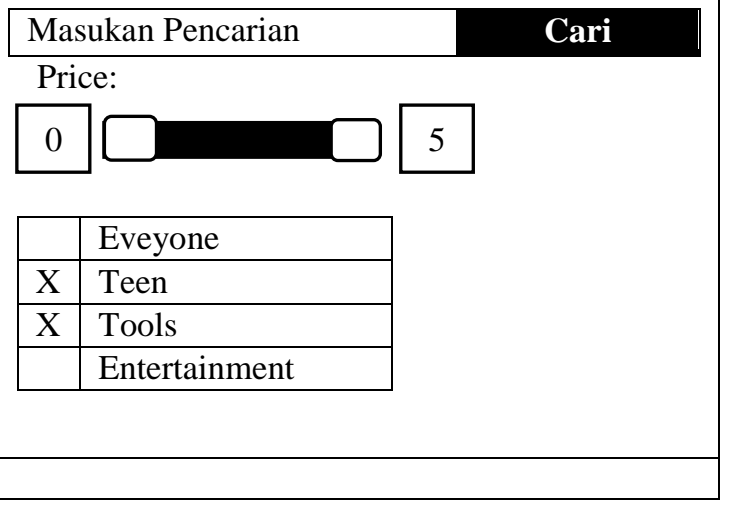

Gambar 3. Halaman pencarian

Halaman pada Gambar 3 merupakan tampilan awal dari sistem Google Play searcher, nama aplikasi untuk sistem pencarian aplikasi pada Google Play yang sesuai dengan kebutuhan pengguna. Pengguna memasukan kata pencarian dan memasukan filter yang diperlukan/diinginkan untuk mendapatkan hasil yang susuai, selanjutnya pengguna mengklik tombol cari untuk mencari aplikasi yang diinginkan.

\begin{tabular}{|c|c|c|c|}
\hline \multicolumn{4}{|c|}{ Google Play searcher } \\
\hline \multicolumn{2}{|c|}{ Masukan Pencarian } & & \\
\hline \multicolumn{2}{|c|}{ Price: } & Icon & Google Fit \\
\hline 0 & & Icon & Nike Running \\
\hline \multicolumn{4}{|c|}{ Your selected: } \\
\hline \multicolumn{2}{|c|}{ Tootls } & Icon & $\mathrm{xx}$ \\
\hline \multicolumn{2}{|c|}{ Teen } & & \\
\hline \multicolumn{2}{|c|}{\begin{tabular}{|l|l|} 
& Eveyone
\end{tabular}} & Icon & $\mathrm{xxxx}$ \\
\hline $\mathrm{X}$ & Teen & & \\
\hline \multirow{2}{*}{$\mathrm{X}$} & Tools & Icon & $\mathrm{xxxxxx}$ \\
\hline & Entertainment & & \\
\hline
\end{tabular}


Halaman pada Gambar 4 merupakan tampilan untuk menampilkan hasil produk yang dicari dengan menambahkan filter. Informasi yang ditampilhan adalah icon produk dan nama produk aplikasi.

\section{Rancangan perbaikan usabilitas fitur pengelolaan}

Perbaikan usabilitas fitur dapat dilakukan untuk mengelola pencarian dan penyaringan dengan menambahkan fitur pada aplikasi.

\section{Pemberian nama template secara otomatis}

Dengan menambahkan pemberian nama template secara otomatis pengguna tidak perlu memikirkan nama template jika ingin melakukan pemberian. Pengguna dapat tetap menggunakan template.

\section{Pengubahan nama template pencarian}

Pengelolaan usabilitas fitur dilakukan dengan pengguna dapat melakukan perubahan judul pencarian template.

\section{Perancangan pencarian judul template}

Dengan menambahkan pencarian judul template pengguna juga dapat dimudahkan dalam menemukan pencarian yang telah disimpan.

\section{IMPLEMENTASI}

\section{A. Lingkungan Implementasi}

Pada pengembangan aplikasi, peneliti menggunakan perangkat keras dengan spesifikasi seperti pada Tabel 2 . Sedangkan untuk perangkat lunak yang digunakan dalam pengembangan aplikasi adalah seperti pada Tabel 3 .

Tabel 2.

Lingkungan implementasi (perangkat keras)

\begin{tabular}{ll}
\hline \hline Perangkat keras & Spesifikasi \\
\hline Laptop & Prosesor: AMD® APU A10- \\
& 8700P 4 CPU Core \\
& RAM: 6GB \\
& Sistem Operasi Windows 10 \\
\hline
\end{tabular}

Tabel 3.

Lingkungan implementasi (perangkat lunak)

\begin{tabular}{ll}
\hline \hline Perangkat lunak & Spesifikasi \\
\hline Web server & Apache \\
Database server & MySQL \\
Bahasa & PHP \\
Framework & Laravel \\
Editor & Atom
\end{tabular}

\section{B. Desain dan Pengembangan Aplikasi}

Halaman pencarian produk pada Google Play berperan sebagai halaman utama dari aplikasi Google Play searcher. Pengguna memasukan kata kunci pada kolom pencarian atau memilih template pencarian yang sudah disediakan dalam bentuk dropdown. Pengguna juga dapat menambahkan penyaringan pencarian untuk mendapatkan produk yang diinginkan. Selanjutnya sistem akan mencocokan kata kunci pencarian dengan hasil pada basis data produk. Jika produk ditemukan, maka pengguna akan ditampilkan halaman hasil pencarian sesuai dengan kata kunci dengan tambahan penyaringan maupun tanpa penyaringan produk yang dicari. Namun, jika pencarian tidak sesuai dengan nama produk yang terdapat dalam basis data, maka sistem tidak akan menampilkan hasil apapun yang menunjukan tidak ada produk yang ditemukan.

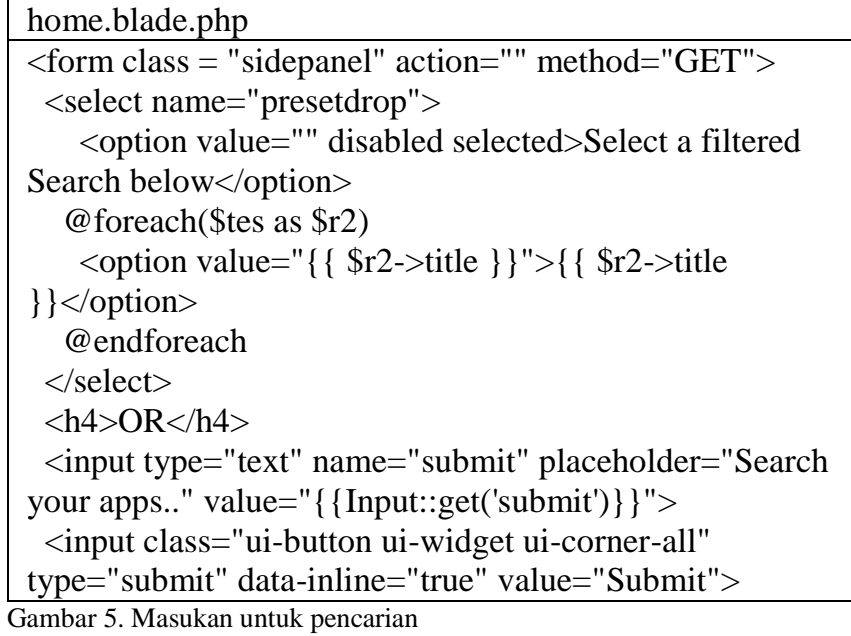

Halaman hasil berisikan hasil pencarian produk yang terdiri dari icon produk, nama produk, pengembang produk, rating dari produk, serta harga produk. Pada halaman ini juga tersedia opsi untuk menyimpan pencarian dan penyaringan yang telah dilakukan. Penyimpanan ini dimasukan ke basis data sebagai template pencarian untuk memudahkan pengguna lain saat mencari produk dengan kata kunci dan penyaringan yang sama. Pengguna harus memberikan judul template untuk dapat menyimpan pencarian dan penyaringan yang telah dilakukan. Apabila tidak diberikan judul, sistem tidak akan memasukan kata kunci dan penyaringan yang telah dilakukan pengguna ke basis data.

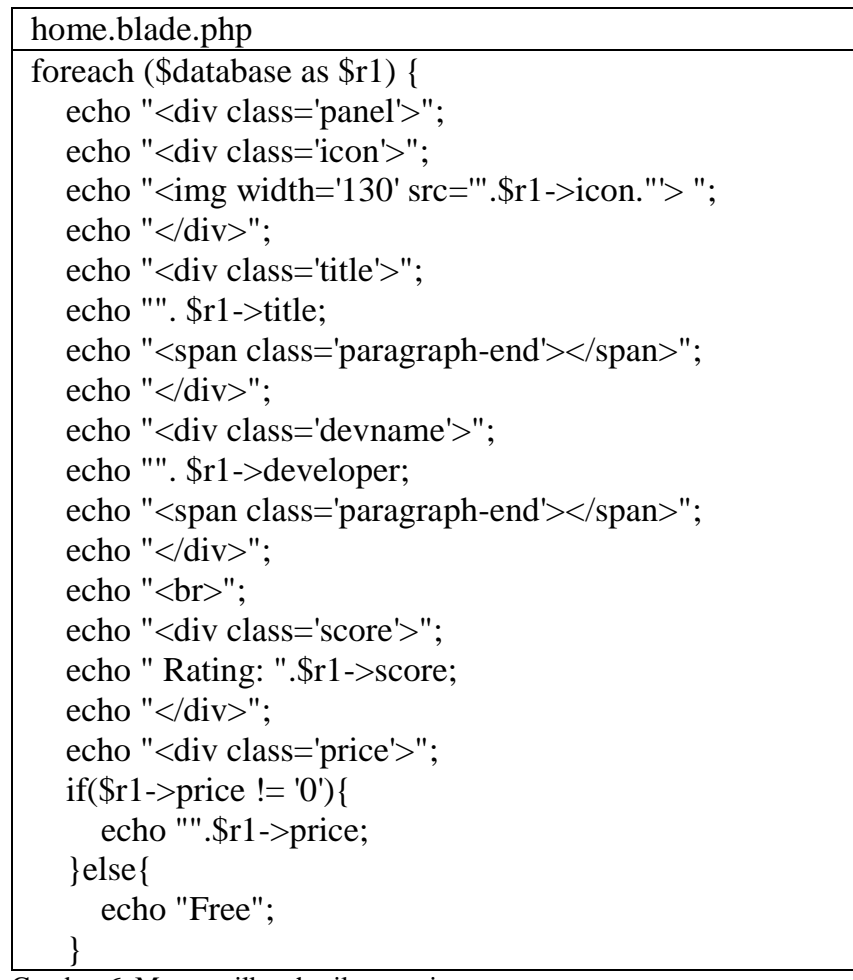

Gambar 6. Menampilkan hasil pencarian 


\section{HASIL DAN PEMBAHASAN}

\section{A. Hasil Prototipe Aplikasi}

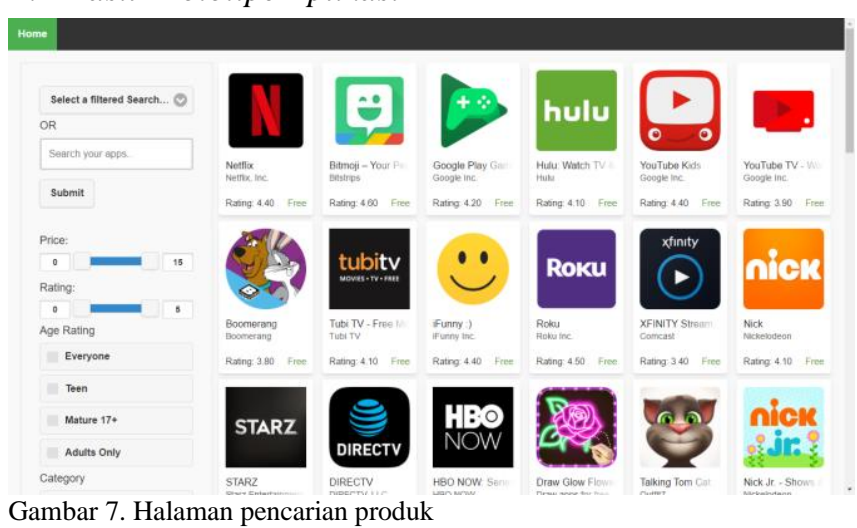

Halaman pada Gambar 7 merupakan halaman awal dari sistem Google Play searcher, nama aplikasi sistem pencarian dan penyaringan untuk memudahkan pengguna dalam mencari produk pada Google Play. Pengguna dapat memilih untuk menggunakan template pencarian atau memasukan kata kunci untuk menemukan produk aplikasi yang dinginkan. Pengguna juga dapat menambahkan penyaringan pencarian berupa range slider maupun checkbox untuk mempersempit pencarian dari produk yang diinginkan.

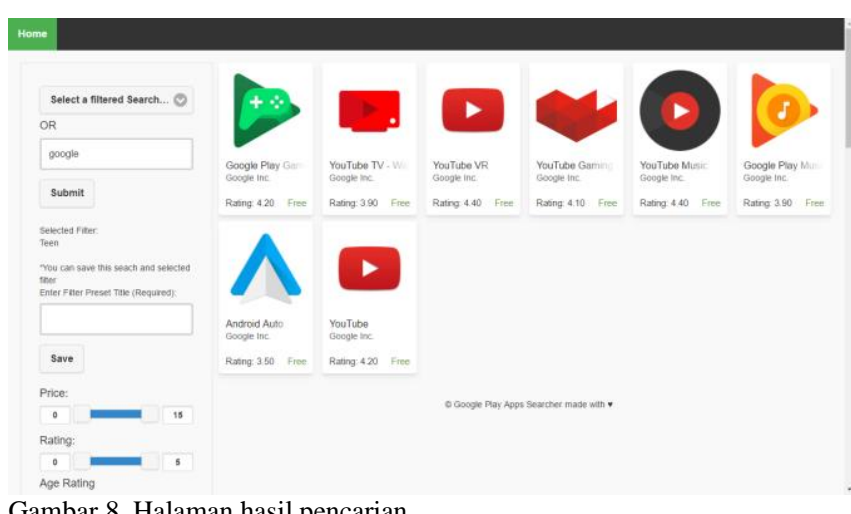

Gambar 8. Halaman hasil pencarian

Halaman pada Gambar 8 merupakan tampilan untuk menampilkan daftar produk sesuai dengan pilihan template atau kata kunci, baik dengan penyaringan maupun tanpa penyaringan. Data yang ditampilkan adalah daftar produk berupa icon, nama, pengembang, rating, dan harga dari produk. Pengguna tidak dapat memilih produk untuk melihat lebih jauh informasi produk. Karena lingkup sistem hanya sampai pada tahap menampilkan saja. Pengguna juga dapat menyimpan pencarian beserta penyaringan yang dilakukan kedalam template pada basis data dengan cara memasukan judul template dan menekan tombol save.

\section{B. Perbikan Usabilitas fitur}

Perbaikan usabilitas fitur yang terimplementasi adalah pemberian nama template secara otomatis.

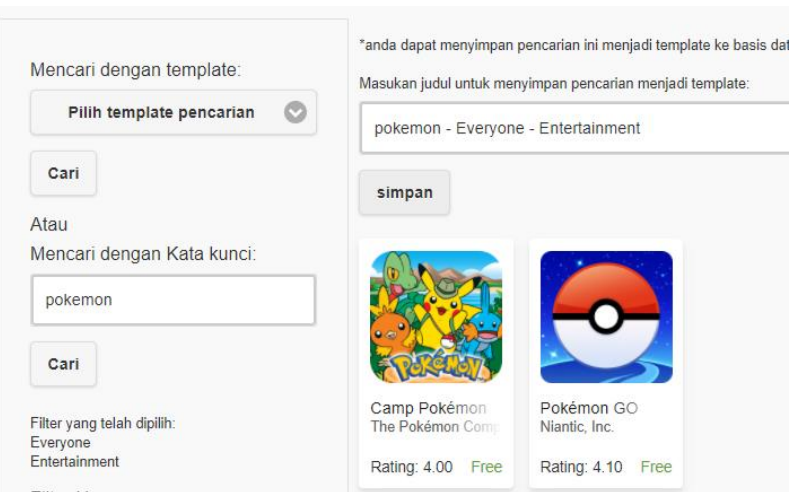

Gambar 9. Hasil pemberian nama template secara otomatis

Kolom penyimpanan yang sebelumnya terletak dibawah penyaringan dipindah bagian atas halaman hasil pencarian. Kemudian nilai yang sebelumnya kosong menjadi terisi secara otomatis berdasarkan kata kunci pencaria dan fiter yang telah dipilih. Sebagai contoh pada Error! Reference source not found. pada kolom penyimpanan judul pencarian telah terisi Pokemon - Everyone - Entertainment yang diambil dari kata kunci dan penyaringan yang dipilih (dapat dilihat pada pojok kiri bawah Error! Reference source not found.)

\section{Hasil Uji Usabilitas}

Uji usabilitas digunakan untuk mengetahui apakah fitur yang diusulkan akan membantu pelanggan dalam mencari produk yang sesuai dengan kebutuhan dirinya dengan bantuan penyaringan. Uji usabilitas dilakukan tanggal 14 Juni 2017 sebanyak 10 responden dengan kondisi sistem telah terbentuk dan siap dijalankan (Apache + MySQL).

Pada akhir setiap sesi usability testing yang dilakukan, responden diminta untuk mengisi kuisioner System Usability Scale (SUS) yang digunakan untuk mengukur kemudahan dari pengunaan aplikasi [11].

Hasil dari System Usability Scale yang diberikan menghasilkan kemudahan dalam penggunaan sebesar $71.25 \%$ sebagaimana yang terlihat pada Gambar 8 .

\begin{tabular}{|l|l|r|r|r|r|r|r|r|r|r|r|r|}
\hline Peserta & Jenis Kelamin & P1 & P2 & P3 & P4 & P5 & P6 & P7 & P8 & P9 & P10 & \\
\hline Fitri Larasati & Perempuan & 4 & 2 & 4 & 1 & 4 & 3 & 5 & 2 & 4 & 1 & $80.0 \%$ \\
\hline Delina Rahayu E & Perempuan & 4 & 2 & 3 & 2 & 3 & 3 & 4 & 2 & 4 & 2 & $67.5 \%$ \\
\hline Haikal Rusdi & Laki-laki & 4 & 1 & 5 & 1 & 4 & 1 & 4 & 1 & 5 & 1 & $92.5 \%$ \\
\hline Ervi Ritya Zulvima & Perempuan & 4 & 2 & 5 & 4 & 3 & 2 & 5 & 2 & 5 & 1 & $77.5 \%$ \\
\hline Marina Safitri & Perempuan & 4 & 1 & 5 & 2 & 5 & 2 & 4 & 2 & 5 & 1 & $87.5 \%$ \\
\hline Dhamar Bagas Wisesa & Laki-laki & 3 & 2 & 4 & 3 & 2 & 3 & 4 & 3 & 4 & 3 & $57.5 \%$ \\
\hline Sasongko Kurniawan & Laki-laki & 4 & 2 & 4 & 2 & 3 & 2 & 4 & 2 & 4 & 2 & $72.5 \%$ \\
\hline Robbigh Faubendri & Laki-laki & 3 & 4 & 2 & 4 & 2 & 2 & 4 & 2 & 4 & 2 & $52.5 \%$ \\
\hline Dhamar Bagas Wisesa & Laki-laki & 3 & 2 & 4 & 3 & 2 & 3 & 4 & 3 & 4 & 3 & $57.5 \%$ \\
\hline Ramadhan Pratama Budiman & Laki-laki & 3 & 2 & 4 & 4 & 5 & 2 & 4 & 1 & 4 & 4 & $67.5 \%$ \\
\hline & & & & & & & & & & Total & $71.25 \%$ \\
\hline
\end{tabular}

Gambar 10. Hasil rekapitulasi SUS

\section{KESIMPULAN DAN SARAN}

\section{A. Kesimpulan}

Berdasarkan pengerjaan studi dengan judul "Rancang Bangun Fitur Pengelolaan Penyaringan Produk Pada Situs Penjualan Produk Perangkat Lunak Untuk Mempermudah Pencarian" yang telah dilakukan dapat disimpulkan beberapa hal sebagai berikut:

1. Aplikasi pencarian dan penyaringan produk pada Google Play telah dibuat berdasarkan kebutuhan yang didapat dari literatur dan wawancara yaitu: 
a. Sistem menyediakan pencarian yang dapat menambahkan penyaringan.

b. Sistem menyediakan penyimpanan pencarian dan penyaringan sebagai template.

c. Sistem menyediakan pencarian menggunakan template untuk membatu pengguna menemukan produk yang pernah dicari oleh pengguna sebelumnya.

2. Metode pengembangan yang digunakan untuk mengembangkan pencarian dan penyaringan produk aplikasi pada Google Play, yaitu prototyping dengan 3 tahapan sebagai berikut:

a. Pengumpulan kebutuhan untuk mengembangkan sistem dengan cara wawancara dari pengguna Google Play.

b. Merancang dan membuat prototype yang disesuaikan dengan kebutuhan sistem yang telah didefinisikan sebelumnya dari wawancara.

c. Melakukan uji coba oleh pengguna. Kemudian dilakukan evaluasi kekurangan dan masukan dari kebutuhan pelanggan.

3. Aplikasi pencarian dan penyaringan telah melewati skenario uji coba untuk semua kebutuhan dengan hasil yang ditampilkan pada sistem sesuai dengan kebutuhan.

\section{B. Saran}

Saran penulis untuk penelitian dan pengembangan selanjutnya adalah sebagai berikut:

1. Untuk penelitian selanjutnya dapat ditambahkan dengan penambahan fitur melihat detail aplikasi.
Detail aplikasi ini digunakan untuk melihat informasi dari produk secara rinci.

2. Aplikasi juga dapat ditambahkan semacam fitur autocomplete dan live search pada kolom input pencarian menggunakan kata kunci. Autocomplete dan live search dapat memudahkan pengguna dalam mencari aplikasi yang diingikan.

Selain penambahan autocomplete dan live search, dapat ditambahkan juga jenis penyaringan yang ada pada google play, seperti menyaring berdasarkan versi android maupun berdasarkan permission aplikasi.

\section{DAFTAR PUSTAKA}

[1] M. Gaasterland, "What is Content Curation? And how it's useful to you and your network.," michielgaasterland, 2011.

[2] D. Tunkelang, "Faceted Search," Synth. Lect. Inf. Concepts, Retrieval, Serv., vol. 1, no. 1, pp. 1-80, Jan. 2009.

[3] A. Zimmermann, M. Specht, and A. Lorenz, "Personalization and context management," User Model. User-Adapted Interact., vol. 15 , no. 3-4, pp. 275-302, 2005.

[4] J. M. Hörnkvist, W. R. Loofbourrow, and E. R. Koebler, "Faceted search results," 2011.

[5] S. Klemmer, "Human-Centered Design: an Introduction University of California, San Diego |Coursera.".

[6] S. S. Experience, An Introduction to Curated Commerce. 2013.

[7] J. Callaham, "The new Google Store is your one-stop web shop for Chromebooks, Nexus devices and more," 2015.

[8] F. Liu, C. Yu, W. Meng, and A. Chowdhury, "Effective keyword search in relational databases," Sigmod, p. 563, 2006

[9] A. S. for P. Affairs, "Usability Testing," 2013.

[10] Y. Wirawan, "Google Play API."

[11] J. Sauro, "MeasuringU: Measuring Usability with the System Usability Scale (SUS)," online, 2011. 